\title{
ब同
}

\section{A Case of Hydatid Cyst Admitted to Emergency with Chest Pain}

\author{
Göğüs Ağrısı ile Başvuran Kist Hidatik Olgusu
}

\author{
Aydın Deniz Karataş ${ }^{1}$, Tevfik Kaplan², Suat Durkaya² \\ 'Iskenderun Devlet Hastanesi, Kıymet Yazıcı Acil Servisi, Hatay, Türkiye \\ ${ }^{2}$ Iskenderun Devlet Hastanesi, Göğüs Cerrahisi Kliniği, Hatay, Türkiye
}

\begin{abstract}
Hydatid disease remains a serious health problem for the Mediterranean countries, such as Turkey. At present Hydatid cyst is an endemic public health problem that is seen especially in some parts of South America, Middle Asia and South Europe. Pleural hydatid cyst is seen rarely and is supposed $r$ to depend on rupture of pulmonary or liver hydatid cysts. A nineteen year old man who took part in sports and was previously completely healthy was admitted to the emergency service with chest pain that began suddenly and was not improving with rest. Thorax tomography was planned because a circular opacity with a $5 \mathrm{~cm}$ diameter is seen in pulmonary radiography of the patient. In the thorax tomography, there was a supported t hydatid cyst image with pleural invasion into the right middle lobe of the lung (pulmonary). The patient was operated on by thoracic surgeons. On the fifth day, the patient was discharged from hospital. Hydatid cysts infect different tissue including the pleura. In emergency service, physicians should notice that the patient with atypical chest pain and pulmonary opacity site in radiography may have a pleural cyst hydatid cyst.
\end{abstract}

Keywords: Cyst hydatic, emergency, chest pain Received: 02.06.2011 Accepted: 04.09.2011

\section{ÖZET}

Kist hidatik günümüzde halen özellikle güney Amerika, Orta Asya ve Güney Avrupa olmak üzere bazı bölgelerde endemik bir halk sağlığı problemidir. Plevral tutulum nadir görülmekle birlikte akciğer ya da karaciğer kist hidatik rüptürüne ikincil olarak geliştiği düşünülmektedir. Öncesinde hiçbir klinik hikayesi olmayan, aktif spor yapan on dokuz yaşında erkek hasta, futbol antremanı sırasında koşu yaparken ani başlayan ve dinlenme ile düzelmeyen göğüs ağrısı nedeniyle acil servisimize başvurdu. Hastanın alınan akciğer radyografisinde sağ orta loba uyan bölgede düzgün kenarlı yaklaşık $5 \times 5 \mathrm{~cm}$ genişliğinde yuvarlak bir opasite tespit edilmesi üzerine toraks tomografisi planladı. Hastanın toraks tomografisinde sağ orta lobda plevral tutulumda gösteren kist hidatik ile uyumlu görüntü mevcuttu. Servise yatırılan hastaya göğüs cerrahisi tarafından total kistektomi operasyonu yapılarak yatışının 5. gününde şifa ile taburcu edildi. Kist hidatik plevra da dahil olmak üzere çok farklı dokularda karşımıza gelebilir. Atipik göğüs ağrısı ile karşımıza çıkan ve akciğer grafisinde opasite tespit edilen olguların kist hidatik hastası olabileceği akla gelmelidir.

Anahtar Kelimeler: Kist hidatik, acil, göğüs ağrısı Geliş Tarihi: 02.06.2011 Kabul Tarihi: 04.09.2011

\section{Giriş}

Kist hidatik günümüzde halen özellikle Güney Amerika, Orta Asya ve Güney Avrupa olmak üzere bazı bölgelerde endemik bir halk sağlığı problemidir (1). Echinococcus granulosus parazitinin neden olduğu kist hidatik çoğunlukla karaciğer ve akciğerde görülmekle beraber nadir de olsa herhangi bir organ ve yumuşak dokuda da görülebilir $(2,3)$. Ekstrapulmoner intratorasik tutulumlara az sıklıkla rastlanmaktadır ve genellikle mediastinum, plevra, perikardiyum ve göğüs duvarı tulumu meydana gelmektedir (3). Plevral tutulum nadir görülmekle birlikte akciğer ya da karaciğer kist hidatik rüptürüne ikincil olarak geliştiği düşünülmektedir (4). Biz burada plevral tutulumun eşlik ettiği bir pulmoner kist hidatik olgusunu sunmaktayız.

\section{Olgu Sunumu}

Öncesinde hiçbir klinik hikayesi olmayan, aktif spor yapan on dokuz yaşında erkek hasta, futbol antremanı sırasında koşu yaparken ani başlayan ve dinlenme ile düzelmeyen göğüs ağrısı nedeniyle acil servisimize başvurdu. Hasta ağrısının özellikle 
nefes alıp verme ile meydana geldiğini ve iğne batar tarzda olduğunu ifade etmekteydi. Hastanın acil servisimizdeki ilk değerlendirmesinde, genel durumunun iyi, bilincinin açık ve vital bulgularının stabil olduğu tespit edildi. Solunum sistemi muayenesi tamamen doğal olarak değerlendirildi. Laboratuar çalışmasında biyokimyasal parametreler (Glukoz, BUN, Kreatin, Bilurubin, ALT, AST, Amilaz, Lipaz, Sodyum, Potasyum, Kalsiyum) normal sınırlarda idi. Sedimentasyon normal sınırda $18 \mathrm{~mm} / \mathrm{h}$ olarak tespit edildi. Hastanın tam kan sayı-

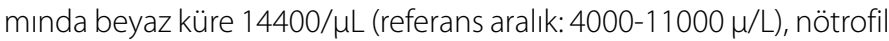

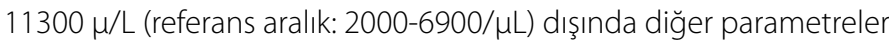
(hemoglobin, hematokrit, platellet) normal sınırlardaydı. Hastanın alınan akciğer radyografisinde sağ orta loba uyan bölgede düzgün kenarlı yaklaşık $5 \times 5$ cm genişliğinde yuvarlak bir opasite tespit edilmesi üzerine toraks tomografisi planladı (Resim 1). Hastanın toraks tomografisinde sağ orta lobda plevral tutulumunda eşlik ettiği kist hidatik ile uyumlu olabileceği düşünülen görüntü mevcuttu (Resim 2). Hasta göğüs cerrahisi ile konsulte edildi. Servise yatırılan hastaya göğüs cerrahisi tarafından total kistektomi operasyonu yapılarak yoğun bakıma yatırıldı. Albendazol 200 mg/gün başlandı. Yatışının 2. günü servise alınan hasta yatışının 5. gününde şifa ile taburcu edildi.
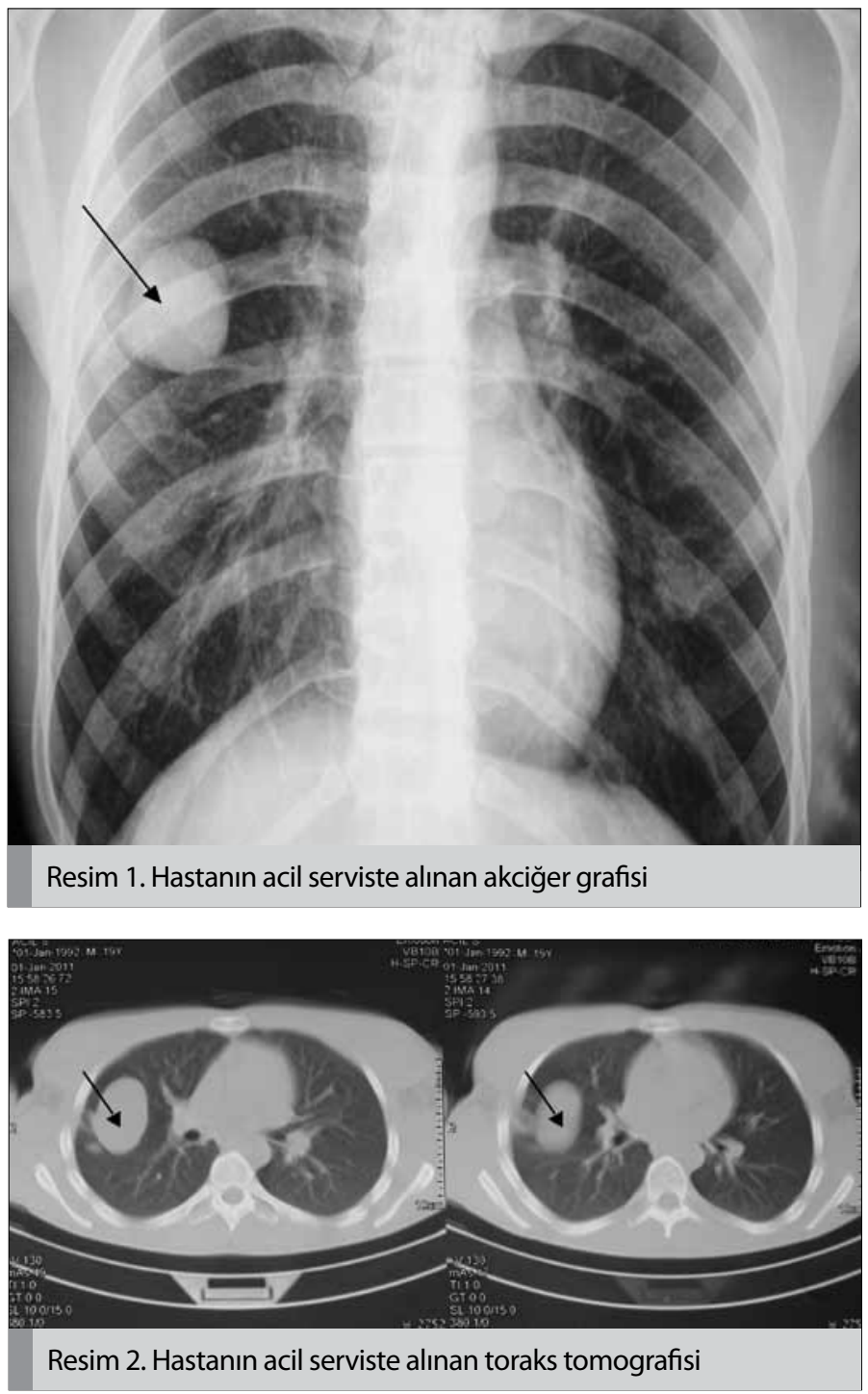

\section{Tartışma}

Kist hidatik özellikle karaciğer, akciğer ve beyni tutma eğilimindedir (3). Ekstrapulmoner intratorasik kist hidatik göğüs duvarı, mediasten, perikard, miyokard, lobar fissur ve plevra lokalizasyonunda bulunabilir (5). Nadiren de olsa kan dolaşımı ile yayılarak plevral kist hidatik tutulumu gerçekleşebilmesine rağmen, genellikle plevral kist hidatik mevcut bir kistin plevranın içine rüptüre olması ve plevra boyunca yayılması sonucu meydana gelir (4). Olgumuzda akciğer sağ orta lobda plevra invazyonu yapan bir kist mevcuttu. Plevral tutulum mevcut olan kistin plevral aralığa rüptüre olması sonucu meydana gelmiş olabilir.

Kist hidatik herhangi bir belirti vermeden uzun süre asemptomatik kalabilir (6). Özyurtkan ve ark.'ları (3) kist hidatik hastalarının \%30'unun asemptomatik seyrettiklerini bildirmişlerdir. Semptomlar kistin yerleşim yerine ve büyüklüğüne bağlı olarak değişkenlik gösterir. Bronşial ve kardiyovaskuler siteme yakın komşuluğu nedeniyle akciğer kist hidatiği daha erken semptom vermektedir. Kist hidatik olgularında öksürük, solunum sıkıntısı, ateş, hemoptizi, göğüs ağrısı, deri döküntüleri gözlenebilir. Sekonder bronşektazi, ampiyem, sekonder amiloidoz, vena kava superior sendromu ve horner sendromu ile ilişkili bulgular ortaya çıkabilir. En tanısal semptom, perforasyona bağlı kist sıvı veya membranının ekspektorasyonudur (hidoptizi) (7). Semptomlar genellikle kistin ve/veya komplikasyonlarının akciğer dokusuna bası yapması sonucu meydana gelir (3). Plevraya rüptür olmuş kist hidatik eizonifilik plevral efüzyona ya da plevral ampiyeme neden olabilir (8). Özyurtkan ve ark'.larının (3) sunduğu plevral kist hidatik olgusunda öksürük ve solunum sıkıntısı belirtmişlerdir. Bu olgunun tek semptomu akut başlangıçlı nefes alıp vermek ile değişen iğne batar tarzda göğüs ağrısı idi. Bu göğüs ağrısının aslında akciğerde mevcut kistin plevral aralığa rüptüre olması ve plevrayı irite etmesi sonucu meydana geldiğini düşünmekteyiz.

Kist hidatik tanısı için en önemli faktör hastalığın öncelikle akla getirilmesidir. Kist hidatiğin tanısı kombine radyolojik incelemelerle kolayca konulabilir. Günümüzde en sık kullanılan yöntemler toraks tomografisi ve ultrasonografidir. Çok kesitli tomografi, geleneksel tomografilere göre bu konuda daha iyi fikir verirken, koronal, sagital ya da oblik kesitlerle lezyon daha iyi değerlendirilebilir (9). Bu olguda öncelikli olarak akciğer grafisi alınmıştı. Akciğer grafisindeki opasitenin detaylı görüntülenmesi amacıyla alınan toraks tomografisinde kist hidatik ile uyumlu görüntü mevcuttu.

Akciğer kist hidatiğin temel tedavisi cerrahidir (9). Kist hidatik etrafındaki doku ile birlikte tamamen çıkarılır (1). Albendazol'ü içeren medikal tedavi özellikle cerrahi olarak tamamen çıkarılamayan olgularda cerrahi prosedüre eklenir. Ayrıca cerrahi tekniğin zor olduğu veya morbidite ya da mortalite olarak yüksek riskli olan olgularda medikal tedavi alternatif olarak kullanışıdır (3). İlaç tedavisi ile başarı \%36-94 gibi çok geniş bir aralıkta bildirilmektedir. Illaç tedavisi kisti öldürmekle birlikte, membran yerinde durmaktadır. Bu da abse, bronşektazi ya da hemoptizi gibi ciddi komplikasyonlara yol açmaktadır. Bu nedenle uygun vakalara cerrahi tedavi, ilaç tedavisine tercih edilmelidir (9). Bu olguda öncelikli olarak cerrahi tedavi tercih edildi. Olguya total kistektomi operasyonu yapıldı. Eş zamanlı olarak albendazol tedavisi başlandı. 


\section{Sonuç}

Kist hidatik plevra da dahil olmak üzere çok farklı dokularda karşımıza gelebilir. Bazen hiçbir semptom vermeden tesadüfen ya da atipik semptomlarla karşımıza çıkabilir. Atipik göğüs ağrısı ile karşımıza çıkan ve akciğer grafisinde opasite tespit edilen olguların bir kist hidatik hastası olabileceği akla getirilmelidir.

\section{Çıkar çatışması}

Yazarlar herhangi bir çıkar çatışması bildirmemişlerdir.

\section{Kaynaklar}

1. Yorgancı K, Sayek I. Surgical treatment of hydatid cysts of the liver in the area of percutaneous treatment. Am J Surg 2002; 184: 63-9. [CrossRef]

2. Kütükçü E, Kapan S, Turhan AN, Ede B, Aygün E. Pankreatik kist hidatik: Olgu sunumu. Bakırköy Tıp Dergisi 2005; 2: 74-6.
3. Özyurtkan MO, Koçyiğt S, Çakmak M, Özsoy IE, Balcı AE. Case report: secondary pleural hydatidosis. Türkiye Parazito Derg 2009; 33: 177-8.

4. Skerrett SJ, Plorde JJ. Parasitic infections of the pleural space. Semin Respir Med 1992; 13: 242-58. [CrossRef]

5. Oğuzkaya F, Akçali Y, Kahraman C, Emiroğullari N, Bilgin M, Sahin A. Unusually located hydatid cysts: intrathoracic but extrapulmonary. Ann Thorac Surg 1997; 64: 334-7. [CrossRef]

6. Öztürk I, Dilek TUK,Gürses I, Dilek S. Pirimer ovaryen kist hidatik: olgu sunumu. TJOD Derg 2009; 6: 286-9.

7. Önen A, Şanlı A, Avcı BY. Akciğerin dev kist hidatiği: 10 olgu sunumu. Toraks Dergisi 2004; 5: 106-9.

8. Aktoğu Ozkan S, Erer OF, A Yalçin Y, Yuncu G, Aydoğdu Z. Hydatid cyst presenting as an eosinophilic pleural effusion. Respirology 2007; 12 462-4. [CrossRef]

9. Şahin E, Karadayı Ş, Nadir A, Kaptanoğlu M. Diyafragmatik kist hidatik: Olgu sunumu. Cumhuriyet Tıp Dergisi 2009; 31: 452-5. 